\title{
Species-specificities of Myosin Heavy Chain in Setting and Returning*1
}

\author{
Eiji Niwa*2, Kenji Koshiba*2, Michio Matsuzaki ${ }^{* 2}$, Teruo NaKayama*2, \\ and Iwao HAMADA*2
}

(Received July 21, 1980)

\begin{abstract}
An elastic gel is formed by standing fish flesh sol at $0-50^{\circ} \mathrm{C}$ (setting), while at about $60^{\circ} \mathrm{C}$, the once formed gel is disintegrated (returning). The visco-elasticities of the heated products of myosin heavy chains from various sources were studied in order to clarify their species-specificities in the ease to set and the ease to return.

Gels were prepared by grinding the heavy chain coagula with $3 \%$ sodium chloride, and heating at $40^{\circ} \mathrm{C}$ for $30 \mathrm{~min}$ in the setting and at $60^{\circ} \mathrm{C}$ for $120 \mathrm{~min}$ in the returning. At $40^{\circ} \mathrm{C}$, elastic gels were formed from fine-spotted flounder, black scraper and jack mackerel; the brittle gels were formed from yellow tail, carp and spanish mackerel; but none was formed from hen, beef and pork. At $60^{\circ} \mathrm{C}$, the gels were formed from the above species except black scraper and spanish mackerel.

Viscosities of the heavy chain solutions from jack mackerel $(2.0 \mathrm{mg} / \mathrm{m} /)$ and flatfish $(3.0 \mathrm{mg} / \mathrm{m} /)$ increased during heating at $40^{\circ} \mathrm{C}$, while those from carp $(5.0 \mathrm{mg} / \mathrm{m} l)$, hen $(6.5 \mathrm{mg} / \mathrm{m} l)$ and beef $(5.7 \mathrm{mg} / \mathrm{m} l)$ did not.

The viscometric behaviors of flatfish and carp actomyosin solutions were observed to be similar to that of the heavy chain solution from each fish.

From the above results, it was presumed that the difference in the gel-forming abilities among the muscles of the various species was eventually attributed to the difference among the heavy chains.
\end{abstract}

The elasticities of fish flesh gels (kamaboko) from various fishes are thought to be eventually attributed to their myosins ${ }^{1), * 3}$. Myosin is, as well known, composed of heavy chain and light chains, both of which are known to be speciesspecific $^{2)}$. The participation of the myosin in the elasticities can be considered to result from the heavy chain rather than from light chains which are much smaller than the former in molecular weight. This paper deals with that the ease in the gel-formation of fish flesh sol at relatively low temperature (setting) and the disintegration of the once formed gel at about $60^{\circ} \mathrm{C}$ (returning) are attributed to the myosin heavy chain from each fish.

\section{Experimental}

Myosin Heavy Chain, Its Gelation and Elasticity Measurements

Jack mackerel, Trachurus japonicus, black scraper, Navodon modestus, and spanish mackerel, Scomberomorus niphonica, were chilled overnight with ice-flake after fished in the sea near Tsu.
Frozen beef (shank) and pork (ham) were obtained at market. Carp, Cypurinus carpio, yellow tail, Seriola quinqueradiata, fine-spotted flounder, Pleuronichthys cornutus, flatfish, Kareius bicoloratus, and hen were killed by decapitation immediately before experiments. Myosin heavy chain was prepared as reported previously ${ }^{3)}$ from myosin by the treatment with $2 \mathrm{M} \mathrm{LiCl}(\mathrm{pH} \mathrm{11.35})$, its coagulum was collected by centrifugation at $10,000 \times g$ for $15 \mathrm{~min}$ and ground with sodium chloride $(3 \%$ of the coagula) for $5 \mathrm{~min}$ in a mortar.

The resulting heavy chain sol was poured into a glass tube ( $7 \mathrm{~mm}$ radius, $20 \mathrm{~mm}$ height) gummistoppered at its bottom. After sealing the top of the tube with film, the sol was water-bathed at $40^{\circ} \mathrm{C}$ for $30 \mathrm{~min}$ in the setting and at $60^{\circ} \mathrm{C}$ for $120 \mathrm{~min}$ in the returning, and then cooled with running water. The elasticity of the gel was measured at room temperature using a compression creep meter designed by the authors (Fig. 1). Same weights were put on the both weighing pans of the balance. After the approximate equilibrium of the balance was reached, the electric zero balance was

*1 Presented partly at the Ann. Meet. of Japan. Soc. Sci. Fish., Shimizu, Oct. 1978, and Tokyo, Apr. 1979.

*2 Faculty of Fisheries, Mie University, Tsu 514, Japan (丹羽栄二・小柴健阔・松崎道夫 - 中山照雄 - 浜田 儆: 三重大学水産学部).

*3 Presented by F. Nishioka, R. Machida, and Y. Shimizu, and further by Y. SHimizu, S. Setsu, and R. MACHIDA at the Ann. Meet. of Japan. Soc. Sci. Fish., Tokyo, Apr. 1978. 


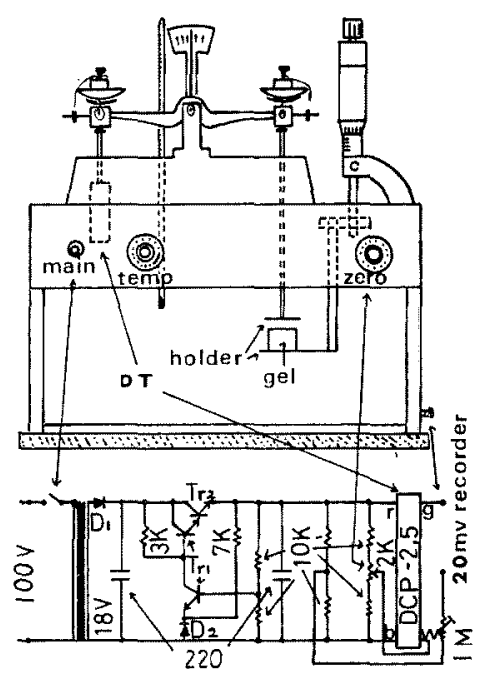

Fig. 1. Apparatus for creep measurement and its electronic circuits. zero: electric zero balance, DT: differential transformer (Shinko Denshi DCP-2.5), D1: SW-1-02, D2: RD-6A, Tr1: 2SC372, and Tr2: 2SC959.

adjusted so that the recorder indication swung around zero with the swing of the pans. The gel was pulled out carefully from the tube with the aid of needle and put on the lower holder jointed with a micrometer. The lower holder was elevated by turning the micrometer, till the top of the gel was brought into contact with the upper holder. This contact was judged by the settling of the recorder pen at zero.

Removing the left weight quietly, the gel was compressed. The shrink of the gel, which was detected with the differential transformer, was recorded with the passage of time. The height of the gel was obtained from the micrometer reading, when the top of the gel was in contact with the upper holder. The instantaneous modulus was calculated from the strain at zero time.

\section{Other Measurements}

The purities of the myosin heavy chains were obtained from the area of the densitogram pattern of $10 \%$ SDS gel electrophoresis ${ }^{8)}$. The water contents of the gels were obtained from its weight loss during heating at $120^{\circ} \mathrm{C}$ for $120 \mathrm{~min}$.

Plunger test $\left.{ }^{4}\right)$ was carried out supplementarily on the fish flesh gels prepared from fine-spotted flounder and beef, because their ease to set or return had not been described yet, differing from the other species used in this study. For the prepa-
Table 1. Purities of starting myosin heavy chains, elastic moduli of resulting gels and water contents of the gels

\begin{tabular}{|c|c|c|c|c|}
\hline \multirow[t]{2}{*}{ Species } & \multirow{2}{*}{$\begin{array}{c}\text { Purity } \\
(\%)\end{array}$} & \multicolumn{2}{|c|}{$\begin{array}{l}\text { Instantaneous*1 } \\
\text { elastic modulus } \\
(\mathrm{Pa})\end{array}$} & \multirow{2}{*}{$\begin{array}{c}\text { Water } \\
\text { content } \\
(\%)\end{array}$} \\
\hline & & $40^{\circ} \mathrm{C}$ & $60^{\circ} \mathrm{C}$ & \\
\hline$\overline{\text { Carp }}$ & 82 & 760 & 770 & 92.3 \\
\hline Yellow tail & - & 890 & 970 & 93.1 \\
\hline Jack mackerel & 100 & 1,090 & 890 & 92.6 \\
\hline Fine-spotted flounde & ler 92 & 1,390 & 490 & 92.3 \\
\hline Black scraper & 98 & 1,200 & -*2 & 92.8 \\
\hline Spanish mackerel & 91 & 660 & —*2 & 93.6 \\
\hline Hen & 97 & $-* 2$ & 1,800 & 92.8 \\
\hline Beef & 95 & - $^{* 2}$ & 1,600 & 92.2 \\
\hline Pork & 86 & 一 $^{* 2}$ & 1,130 & 92.7 \\
\hline
\end{tabular}

Table 2. Plunger tests for fish flesh gels from finespotted flounder and beef

\begin{tabular}{|c|c|c|c|}
\hline \multirow[b]{2}{*}{ Species } & \multirow[b]{2}{*}{$\begin{array}{l}\text { Method of } * 1 \\
\text { gel formation }\end{array}$} & \multicolumn{2}{|c|}{ Plunger test*2 } \\
\hline & & $\begin{array}{l}\text { Breaking } \\
\text { stress } \\
\text { (N) }\end{array}$ & $\begin{array}{l}\text { Breaking } \\
\text { strain } \\
(\mathrm{mm})\end{array}$ \\
\hline \multirow{3}{*}{ Fine-spotted flounder } & $\mathbf{A}$ & 0.7 & 7.1 \\
\hline & B & 1.2 & 5.3 \\
\hline & $\mathrm{C}$ & 0.5 & 5.7 \\
\hline \multirow{3}{*}{ Beef } & A & 7.1 & 10.4 \\
\hline & B & 5.6 & 8.9 \\
\hline & $\mathrm{C}$ & 6.8 & 9.2 \\
\hline
\end{tabular}

*1 Prepared by heating flesh sol, A) at $80^{\circ} \mathrm{C}$ for $60 \mathrm{~min}$, B) at $40^{\circ} \mathrm{C}$ for $30 \mathrm{~min}$, and then at $80^{\circ} \mathrm{C}$ for $60 \mathrm{~min}$, and C) at $60^{\circ} \mathrm{C}$ for $120 \mathrm{~min}$, and then at $80^{\circ} \mathrm{C}$ for $60 \mathrm{~min}$.

* Carried out using spherical plunger (3 mm radius). Sample was column type ( $15 \mathrm{~mm}$ radius, $25 \mathrm{~mm}$ height). Breaking stress is represented as relative values calculated by neglecting the area of the tip of the plunger.

ration of the fish flesh gel $^{x /}$, the flesh mince was washed 3 times with ice-water. After removing the sewage through cloth, the washed mince was ground for $5 \mathrm{~min}$ with $15 \%(\mathrm{w} / \mathrm{w})$ of water against the mince, and further ground for $25 \mathrm{~min}$ with $3 \%(w / w)$ of sodium chloride. Packed sol was heated at definite temperatures as shown in Table2.

Viscosity changes of the heavy chain and actomyosin solutions were recorded with Tokyo Keiki BL-type coaxial viscometer (Ri/Ro: 0.900, Speed: $6 \mathrm{rpm})$.

Protein was determined by the method of UMEMOTO ${ }^{33}$.

\section{Results and Discussion}

Table 1 shows the purities of the starting heavy 
chains, the elastic moduli of the resulting gels and the water contents of the gels. The purities were $85-100 \%$ and the water contents were $92-93 \%$. No correlation of the elastic moduli to the water contents and the purities can be detected. At $40^{\circ} \mathrm{C}$, the elastic gels were formed from fine-spotted flounder, black scraper and jack mackerel, the brittle ones were formed from yellow tail, spanish mackerel and carp, and no gel was formed from hen, beef and pork. At $60^{\circ} \mathrm{C}$, the gels were formed chicken, beef, pork, yellow tail, jack mackerel, carp and fine-spotted flounder. The elastic modulus of the gel decreased in this order, and the ease to form the gel was not in agreement with that at $40^{\circ} \mathrm{C}$.

Table 2 shows the effect of preheating the starting flesh sols from fine-spotted fiounder and beef at different temperatures on the elasticities of the resulting flesh gels. For fine-spotted flounder, a remarkable increase by preheating at $40^{\circ} \mathrm{C}$ and the decrease by preheating at $60^{\circ} \mathrm{C}$ were observed in the breaking stress, while for beef, not so remarkable change was observed at each temperature. Therefore, the former species is thought to be easy to set and return, however, the latter species to be hard to set and return.

On the other hand, jack mackerel, ${ }^{7-10)}$ yellow tail $^{8)}$, black scraper ${ }^{10)}$ and spanish mackerel (seerfish $^{\text {s) }}$ are known to be easy to set, carp ${ }^{p)}$ is hard to do, and hen ${ }^{10)}$ and pork ${ }^{5,14)}$ are entirely to do. From the comparison of the results in Table 1 with the ease to set described in Table 2 and above, it is obvious that the elastic gels were formed from the species easy to set and not formed from those hard to set or entirely hard to set.

Furthermore, black scraper ${ }^{10)}$ and spanish mackerel ${ }^{\text {j) }}$ are known to be extremely easy to return, and hen ${ }^{10,14)}$ pork $^{5,143}$ and beef (Table2) are entirely hard to do. Therefore, it is thought that the species entirely hard to return give elastic gels from their heavy chains at $60^{\circ} \mathrm{C}$, but the species extremely easy to return, such as black scraper and spanish mackerel, do not give gel.

Fig. 2 (Above) shows the viscosity change of the heavy chain solutions from several species during at $40^{\circ} \mathrm{C}$. The solutions from jack mackerel and flatfish, a species easy to $\operatorname{set}^{8)}$, increased remarkably in the viscosity, but those from carp, beef and hen decreased rather in spite of their higher concentration. Fig. 2 (Below) shows the viscosity change of actomyosin solutions, one of the model for muscle as to the gel-forming ability.

The viscosity increased remarkably for flatfish,

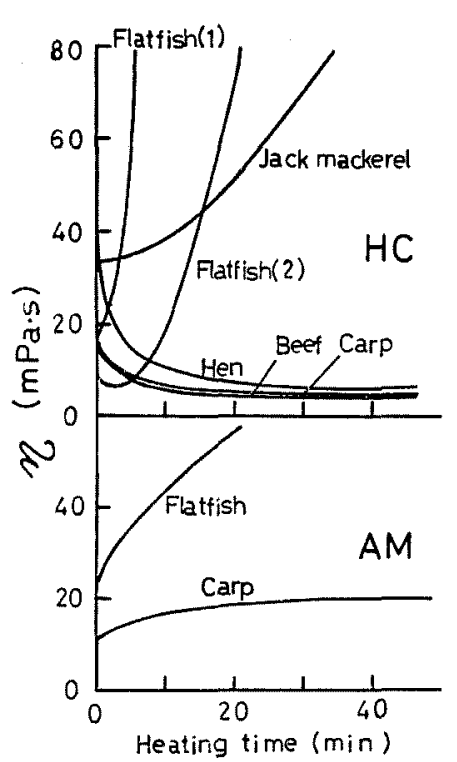

Fig. 2. Viscosity change of myosin heavy chain (HC) and actomyosin (AM) solutions from various species during heating at $40^{\circ} \mathrm{C}$.

Above: heavy chains from flatfish (1: $5.0 \mathrm{mg} / \mathrm{ml}$ and 2: $3.0 \mathrm{mg} / \mathrm{m} l)$, jack mackerel $(2.0 \mathrm{mg} / \mathrm{m} l)$, hen $(6.5 \mathrm{mg} / \mathrm{ml})$, beef $(5.7 \mathrm{mg} / \mathrm{ml})$, and carp $(5.0 \mathrm{mg} / \mathrm{ml})$.

Below: actomyosins from flatfish and carp $(5.0 \mathrm{mg} / \mathrm{ml}$ for both fishes).

but did not for carp. Such viscometric behaviors of the actomyosins from the both fishes is same as that of the heavy chain from each fish. Therefore, it is obvious that not only the actomyosin, but also the myosin heavy chain is more easy to increase in the viscosity, in the species easy to set than in that hard to do. Same increase in the viscosity during heating has been reported on the salt-extract of lizardfish ${ }^{12)}$, a species easy to set, and on the myosin solutions from carp and hen $^{133}$. Carp is more easy to $\operatorname{set}^{14)}$ and its viscosity increases more remarkably than hen ${ }^{13)}$. Such an increase in the viscosity is interpreted by the association between protein molecules ${ }^{12,13)}$.

From these results, it is presumed that the myosin heavy chains from various species indicate species-specificities in the ease to set or return, and the ease is in good agreement with that of each actomyosin or muscle itself. This suggests that the difference in the elasticity of the fish flesh gel among the muscles of various species can be eventually attributed to the structural difference among the heavy chains which compose the myosins. 
In actual fish flesh gel, however, the speciesspecificities must not be attributed to the heavy chain alone, because its interaction with other components would also affect the elasticities. In this relation, it should be noticed that the setting is associated with the interaction between myosin and $\operatorname{actin}^{18), * 1}$ and that the myosin from the fish easy to return is easy to dissociate the light chains. ${ }^{* 2}$

The authors wish to thank Prof. Y. SHimizu and Mr. F. NishioKa, Faculty of Agriculture, Kochi University, for their kind reading of the manuscript, and also KieiKal, for the supporting this study.

\section{References}

1) K. IWATA, K. KANNA, and M. OKADA: Bull. Japan. Soc. Sci. Fish., 43, 237 (1977).

2) D. H. Jean, R. W. Albers, L. Guth, and H. J. ARON: Exp. Neutrol., 49, 750-757 (1975).

3) E. Niwa, T. NaKayama, and I. Hamada: Bull. Japan. Soc. Sci. Fish., 46, 867-870 (1980).

4) E. Niwa, T. Konagaya, and M. Miyake: Bull. Agr. Chem. Soc. Japan, 46, 295-301 (1972).

5) E. Niwa: in "Visco-elasticities of Foods" (ed. by S. Matsumoto), Vol. 3, Shokuhin-shizaiKenkyukai, Tokyo, 1977, pp. 19-30.

6) S. Umemoto: Bull. Japan. Soc. Sci. Fish., 32, 427-435 (1966).

7) W. Simidu: Bull. Japan. Soc. Sci. Fish., 12, 165172 (1944).

8) M. OKadA: Bull. Tokai Reg. Fish. Res. Lab., No. 24, 67-72 (1959).

9) Y. Shimizu: Bull. Japan. Soc. Sci. Fish., 40, 175-179 (1974).

10) Y. Shimizu: in "White Meat Fish and Red Meat Fish" (ed. by Japan. Soc. Sci. Fish.), KoseishaKoseikaku, Tokyo, 1976, pp. 175-179.

11) R. TAKashi, K. ARAI, and T. Sarto: Bull. Japan. Soc. Sci. Fish., 36, 169-172 (1970).

12) Y. Simizu, Y. Hosokawa, and W. Simdu: Bull. Japan. Soc. Sci. Fish, 28, 616-622 (1962).

13) T. Nakayama, H. Okuda, E. Niwa, and I. Hamada: Bull. Japan. Soc. Sci. Fish., 40, 937940 (1974).

14) Y. SHIMiZU: in "Mutual Action between Food Stuff Substance" (ed. by M. NAMIKI and $S$. Matsushita), Kodansha, Tokyo, 1980, pp. 173183.

15) T. Taguchi, K. Kikuchi, M. Oguni, M. TanaKa, and K. Suzuki: Bull. Japan. Soc. Sci. Fish., 44, 1363-1366 (1978).

* I Presented by S. Chihara, T. Akahane, T. Tsuchiya, S. Noguchi, K. Ohgami, and J. J. Matsumoto at the Ann. Meet. of Japan. Soc. Sci. Fish., Tokyo, Apr, 1979.

*2 Presented by Y. SHImizU, F. NishioKA, and A. NomurA at the above meeting. 